\title{
Elaboration and Mechanical-Electrochemical Characterisation of Open Cell Antimonial-lead Foams Made by the "Excess Salt Replication Method" for Eventual Applications in Lead-acid Batteries Manufacturing
}

\author{
A. H. Hassein-Bey, ${ }^{a}$ A. -E. Belhadj, ${ }^{a}{ }^{*}$ A. Gavrus, ${ }^{b}$ and S. Abudurac \\ a Laboratory of Biomaterials and Transport Phenomena (LBMTP), \\ University Yahia Fares, Médéa, 26 000, Algeria \\ b Laboratory of Civil and Mechanical Engineering (LGCGM - EA3913), \\ National Institut of Applied Sciences of Rennes - INSA Rennes, France \\ Department of Mechanical Engineering, Faculty of Technology, \\ University Yahia Fares, Médéa, 26 000, Algeria
}

https://doi.org/10.15255/KUI.2020.001

KUI-25/2020

Original scientific paper

Received January 4, 2020

Accepted June 18, 2020

\begin{abstract}
In this study, open cell $25 \%$ antimony-lead alloy foams are fabricated for possible use to lighten thick plates of lead-acid batteries. A new inexpensive and simple variant of the salt replication process is developed and explored. Different morphology and shapes have been successfully obtained with "excess salt replication" method (abbreviated as ESR method). Best porosity of about $68 \%$ is obtained with salt particles size of about $3 \mathrm{~mm}$. SEM and EDXS investigation of the composite salt/antimony alloy before $\mathrm{NaCl}$ leaching revealed the presence of the lead oxides microfilm coating cell walls and becoming lead carbonates after salt removal. Uniaxial compressive behaviour of the resulting cellular materials is studied for foams with porosities between $45 \%$ and $70 \%$, and salt grain size ranging between 2.5 and $5 \mathrm{~mm}$. A higher plateau stress is reached compared to the results obtained in the literature working on the aluminium foams. The reproducibility of the process is proved along samples.
\end{abstract}

\section{Keywords}

Open cell foam, replication process, porosity, lead-acid batteries, stress-strain, SEM images, acid battery, conductivity

\section{Introduction}

Open cell foams are a wide class of porous materials. They can be made from ceramics ${ }^{1}$ or metals like our antimonial alloy foams. Their physical properties are tightly dependent on their mesostructure ${ }^{2}$ that strongly depends on the manufacturing process. Metals like aluminium and magnesium alloys are usually preferred in different engineering applications fields because of their light weight, high stiffness, good thermal stability, and low manufacturing cost. ${ }^{3}$ However, it is interesting to try new metals possessing the same attractive properties for specific applications with simple technology and intermediate density. The balance between cost and performance of cellular metals is the goal of every new process. Nowadays, numerous fabrication methods are well known, and others are in continuous development. Among these processes, the porosity resulting from removable space-holder materials is of great interest. ${ }^{4}$ The salt replication process has been especially extensively studied by many researchers since the nineteen-sixties. This method is available for metals or alloys with melting temperature inferior to the salt process $\left(T_{\mathrm{m} \text { salt }}=801^{\circ} \mathrm{C}\right)$. Chasemi and Tizpar $^{5}$ and even Reinhart ${ }^{6}$ proved the low uniformity corrosion of antimonial lead in seawater, which supposed that the resulting foam would

${ }^{*}$ Corresponding author: Dr. Abd-Elmouneïm Belhadj

Email: belhadj_1@yahoo.fr have the same behaviour at the pore scale. In the energy storage field, antimonial-lead alloys are well known in manufacturing acid battery grids for their high corrosion resistance. Antimony is added to improve the strength and castability of the alloy. ${ }^{7}$ The need to lighten the thick plates of lead-acid batteries and increase their specific surface strongly encouraged this research. For this purpose and other different applications, antimonial-lead alloy porous materials have been successfully produced by a new process named "excess salt replication method" (or ESR method), since, according to our knowledge, there have been no or only a few studies working on such metal foams.

Commonly, the space holder replication technique has many different variants, based on the physical state of the metal (liquid or powder) and the preparation of different nature of salt in a preform (by cold pressure or sintering) ${ }^{8}$ or combined with clay ${ }^{9}$ or the stage of dissolution of the space holder and the binder. ${ }^{2}$ Furthermore, the mixing of salt particles directly in the molten metal to avoid all preform preparation and using a permeable piston to compact the particles and remove excess aluminium was tested successfully. ${ }^{10,11}$ This last study showed that the manual pressure exerted on piston gives foams the least cell wall discontinuity, and the punctured piston helped to remove the extra aluminium melt and let $\mathrm{NaCl}$ particles contact each other. ${ }^{12}$ It was proved that for low-pressure infiltration and high-density preforms, salt dissolution was rapid due to the porous nature of the salt spheres. 


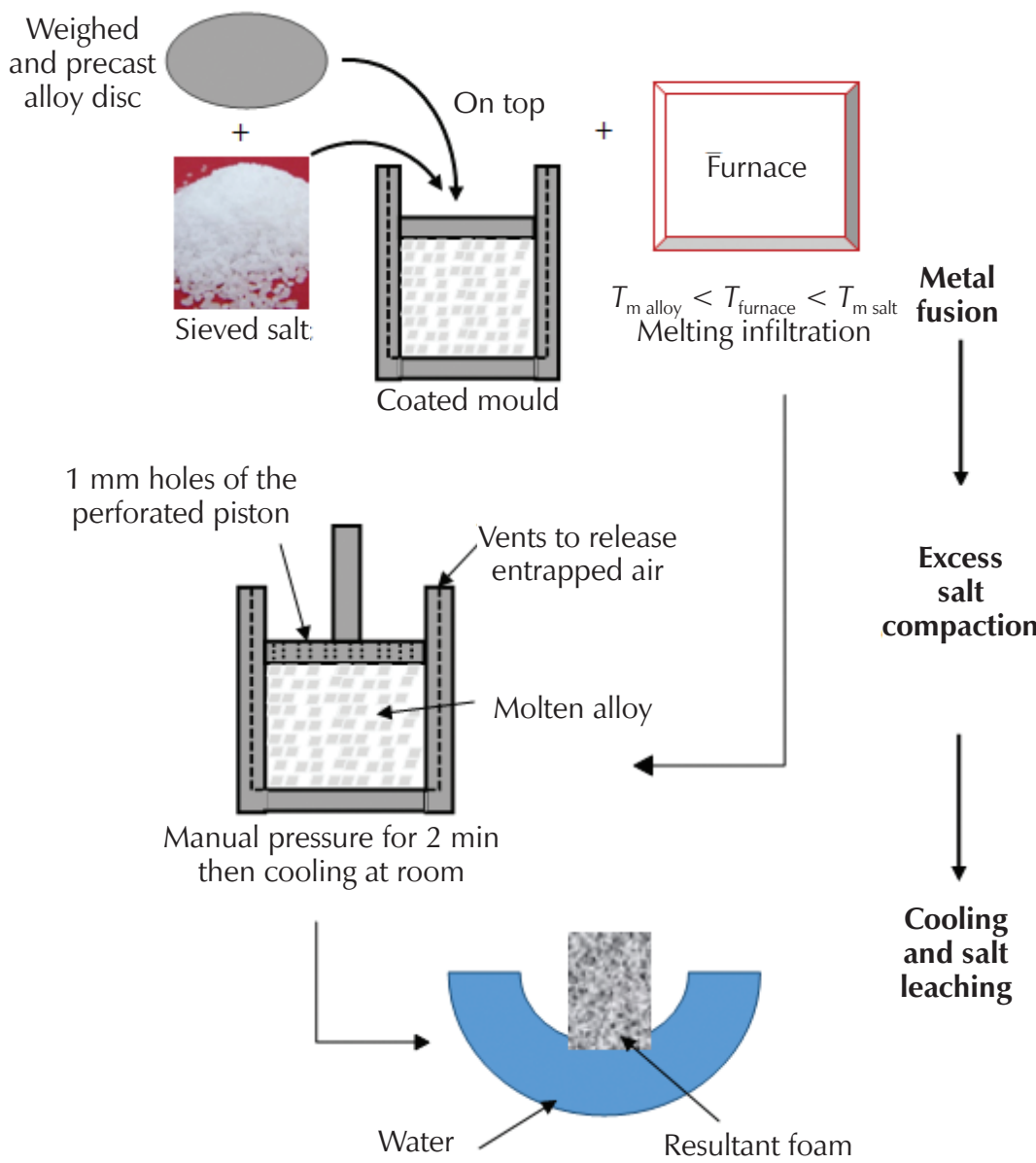

Fig. 1 - Flow diagram concerning the principal steps of the Excess Salt Replication method (ESR): metal fusion with excess salt compaction, finally cooling, and salt leaching

This paper explains how antimony alloy foams can be obtained using a new procedure to avoid extra oxidized metal waste without stirring, which may change the $\mathrm{NaCl}$ particle dimensions causing potential undesirable gas entrapped inside the cellular material. These bubbles can alter the manufactured electrodes.

Firstly, the structure of produced stochastic open cell antimony alloy foam was investigated for different salt grain size at a microscopic level.

Secondly, the conventional mechanical properties in terms of true stress - true plastic strain was explored. Gibson and Ashby have analysed the relation between the plateau stress $\left(\sigma_{\mathrm{p}}\right)$ and the cell materials relative density $\left(\rho / \rho_{0}\right)$, which was given by the following relationship ${ }^{13}$ :

$$
\sigma_{p} / \sigma_{0}=C\left(\rho / \rho_{0}\right)^{3 / 2}
$$

where $\sigma_{0}$ is the solid plastic yield stress, and $C$ is a constant equal to $0.3 .^{13}$ In this study, the results of plateau stress are expected to be more interesting in comparison to the available results in the literature on foams produced with different salt replication methods (mostly aluminium foams). According to the previous studies of $A$. Belhadj \& A.
Gavrus et al. ${ }^{14}$ concerning the description of plateau-stress - relative density variation for metallic open cell foams, new physically-based relationships, proposed by authors, will be taken into account to describe the complete densification, corresponding to the compressive large plastic deformations.

Thirdly, electrochemical response as well as thermal stability of laboratory reproduced cell similar to that of lead-acid battery with sulphuric acid, was also studied. Investigated was the performance of cathodes made from the foams prepared by ESR method compared to a cathode made from the dense alloy of the same composition for a possible application of cellular foams in this field.

\section{Experimental procedure}

Fig. 1 represents the technology principles of the Excess Salt Replication method (ESR method). As leachable space-holder, a commercial salt with six different mean grain sizes between 2.5 and $5.0 \mathrm{~mm}$, and an irregular cubic shape was sieved. The $25 \%$ antimony alloy with lead (tin free), from a commercial white metal supplier, was prepared into precise weighted disc using the same 
iron cast die so that it fitted it later when placed on the salt surface. The interesting properties of the alloy are well known, ${ }^{15}$ which are low proper pouring temperature and good flow characteristics. The perforated piston also had the same inner diameter of the mould and hole diameter below grains size preventing them from going through it during pressure step. The process can be summarised in four principle steps detailed further: metal fusion, excess salt compaction, cooling, and salt leaching.

A weighed mass of desired particle diameter salt was poured in a coated iron mould and gently vibrated to pack in a maximum dense arrangement. In order to prevent its particles from escaping during fusion, the alloy disc was placed in the mould on top of salt surface. The used high temperature furnace was heated from top-bottom and lateral sides by electrical resistance. Once in the furnace, the salt particles were heated simultaneously with the metal disc and infiltration occurred with no need to preheat the salt. The metal disc weight was calculated so that after infiltration, $15 \mathrm{~mm}$ excess salt was gained. This excess salt was compressed manually at room temperature with the perforated piston for $2 \mathrm{~min}$, in order to remove some of the undesired air entrapped in the foam from bottom and top through mould vents and $1 \mathrm{~mm}$ piston's holes, respectively. On the other hand, this pressure made the salt particles contact each other all along the sample. This is where the "ESR process" appellation came from. After one night of cooling at room temperature, samples were ready for metallurgical characterisations. A variety of shapes can be obtained with this process, as shown in Figs. $2 \mathrm{a}$ and $2 \mathrm{~b}$. Before leaching the salt for $24 \mathrm{~h}$ with water, the foams prepared by ESR method were machined in cylindrical composite discs, with height to diameter ratio of $H / D<1.5 .^{13}$ A careful successive grinding and polishing was done using fine and very fine grinding paper with ethanol and hydrocarbon oils suspension slurry for polishing to avoid the dissolution of salt. The morphology of specimens was examined with two different SEM: Quanta 650 scanning electron microscopy and JOEL JSM-6360 equipped with EDAX energy dispersive X-ray spectroscopy detector for the qualitative chemical analysis. The salt was then removed, as shown in Fig. 2c.

The dried specimens of different cell size were weighed and dimensions measured (to determine the density). Standard uniaxial compression under the lubricated platens of 100 kN MTS Criterion C45 electronic universal testing machine was done at $1 \mathrm{~mm} \mathrm{~min}^{-1}$ rate to achieve

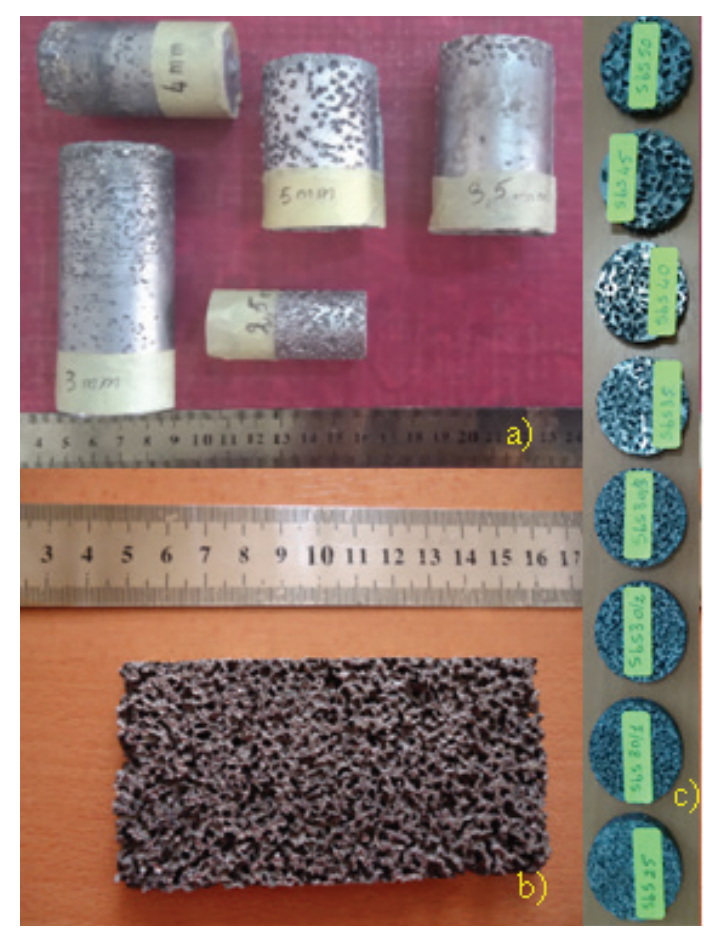

Fig. 2 - Different open cell foam samples obtained by the Excess Salt Replication process (ESR) with antimonial lead alloy for various salt grain size: (a) Cylindrical shapes before $\mathrm{NaCl}$ leaching, (b) Rectangular form after Electrochemical Machining (ECM) prepared for future hydrodynamic and thermal characterisations (SbS20), (c) Samples discs after machining, leaching the salt, and ready for the uniaxial compression test.

60-85\% of deformation. Table 1 synthesizes the obtained morphology and mechanical properties of the samples. It was noticed that the sample densities were independent of the salt grain size.

Plateau stress was graphically obtained as performed by researchers, ${ }^{11,16}$ where the porosity of the samples was determined by Eq. (2):

$$
P=\left(1-\rho / \rho_{0}\right)
$$

where $\rho$ is the apparent density of the sample calculated by its dimensions and weight, $\rho_{0}$ is the measured density of commercial antimonial lead alloy, which is $10.7 \mathrm{~g} \mathrm{~cm}^{-3}$ at

Table 1 - Geometric morphology and mechanical properties of different foams obtained with the Excess Salt Replication (ESR) process

\begin{tabular}{l|r|r|r|r|r|r}
\hline Sample name & SbS25 & SbS30 & SbS35 & SbS40 & SbS45 & SbS50 \\
\hline salt grain size $/ \mathrm{mm}$ & 2.50 & 3.00 & 3.50 & 4.00 & 4.50 & 5.00 \\
\hline samples diameter, $D_{0} / \mathrm{mm}$ & 37.04 & 37.07 & 37.11 & 37.08 & 37.01 & 36.90 \\
\hline samples thickness, $H_{0} / \mathrm{mm}$ & 7.20 & 7.09 & 7.18 & 7.21 & 7.07 & 6.60 \\
\hline samples densities, $\rho / \mathrm{g} \mathrm{cm}^{-3}$ & 3.86 & 3.40 & 5.41 & 4.62 & 5.79 & 4.25 \\
\hline samples porosity, $P / \%$ & 63.86 & 68.25 & 49.46 & 56.79 & 45.93 & 60.28 \\
\hline apparent compressive yield strength, $\sigma_{\mathrm{y}} / \mathrm{MPa}$ & 3.75 & 3.05 & 6.48 & 4.96 & 7.31 & 4.52 \\
\hline
\end{tabular}

Note that the name of samples is "SbS X" which means: Sb for antimony alloy (25 wt\% Sb-Pb), S for salt, and X for a different decimal diameter of salt grain. 
$23{ }^{\circ} \mathrm{C}$ determined in the same way. The ratio $\rho / \rho_{0}$ is called relative density $R_{\mathrm{D}}$ (dimensionless).

To explore the contribution as cellular materials of the obtained foams by ESR process for the improvement of the performance of lead-acid batteries, a series of electrochemical tests were conducted in the laboratory-reconstructed cell. The electrodes made by ESR process were employed as cathodes and commercial dense lead as anodes. The weighed electrodes were immersed into agitating sulphuric acid with pH between 1.11 and 1.25 (Fig. 3 (b)). ${ }^{17}$ They were connected to METEX ME31 Multimeter to check the electrical current flow. A SELECTA CD-2005 Conductivity Meter for electrolyte conductivity measurement and two identical SELECTA pH-2005 pH Meter electrochemical experimental apparatus were used simultaneously to measure the potential difference (voltage), and $\mathrm{pH}$, depending on the time taken by Diamond digital stopwatch. The temperature of $100 \mathrm{ml}$ of sulphuric acid was also measured with a digital thermometer during every manipulation to explore the thermal stability of the cell.

All the experimental apparatus cells were immerged in the sulphuric acid as well as the digital thermometer to measure the initial values $(t=0)$ of electrical conductivity; potential difference, $\mathrm{pH}$, and temperature of the electrolyte before electrode immersion.
Once the electrodes were entirely immersed in the electrolyte, the values of each property of electrical conductivity; potential difference, $\mathrm{pH}$, and temperature were recorded every minute $(t=1 \mathrm{~min}$ ) during the first 10 minutes, then every two minutes until 30 minutes passed (when no noticeable changes of the electrical conductivity of the electrolyte were recorded).

Fig. 3 (a) shows the schematisation of the electrochemical experiences, and Table 2 regroups the used material characteristics and operating conditions of all tested samples.

The battery cells were named "SbSPb X", where SbS stands for the cathodes foams obtained from the ESR process, $\mathrm{Pb}$ is metal used for the lead dense anodes, and $\mathrm{X}$ represents the value of decimal salt grain diameter. In order to highlight the performance of the foams prepared by ESR method and to estimate the relative effective electrical conductivity of the samples, "SbPb dense" cathode as a non-porous $25 \mathrm{wt} \% \mathrm{Sb}$-Pb alloy cathode vs. lead-dense anode were also tested. Density of the cathodes foams was measured by Archimedes' principle. The dependence of the effective electrical conductivity with the relative density of these foams is proposed to be analysed at the end of this study using relationship given by Ashby ${ }^{13}$ for relatively dense cellular materials with an ideal uniform structure, compared to the cuboids structure shape obtained for the proposed cells foams.

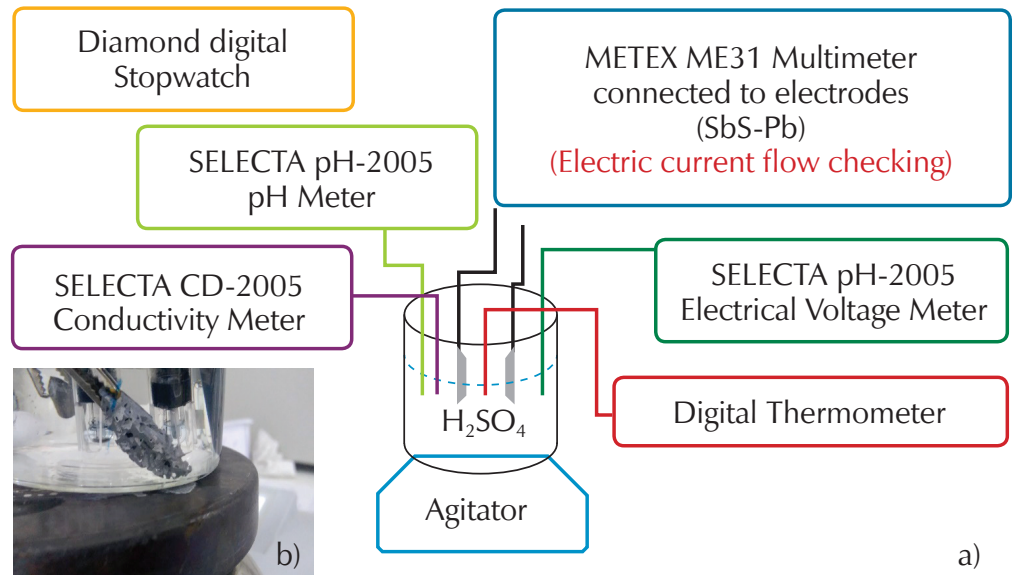

Fig. 3 - (a) Schematic representation of the electrochemical experiments using the mini cells reconstructed in laboratory from the antimony alloy open cell foams obtained by ESR method. (b) Picture of the two electrodes (cathode and anode) immerged in sulphuric acid.

Table 2 - Operating conditions of all experimental tested batteries using open cell foam cathodes obtained from the ESR process and lead $(\mathrm{Pb})$ dense anodes

\begin{tabular}{|l|c|c|c|c|c|c}
\hline Sample name & SbSPb20 & SbSPb30 & SbSPb35 & SbSPb40 & SbSPb50 & SbPb Dense \\
\hline salt grain size $/ \mathrm{mm}$ & 2.00 & 3.00 & 3.50 & 4.00 & 5.00 & - \\
\hline$T_{\text {electrolyte }}(\min -\max ) /{ }^{\circ} \mathrm{C}$ & $19.6-19.8$ & $17.5-17.9$ & $19.5-19.9$ & $17.7-17.8$ & $16.7-17.1$ & $17.3-17.3$ \\
\hline $\mathrm{pH}_{0}-\mathrm{pH}_{\text {end }}$ & $1.13-1.11$ & $1.25-1.29$ & $1.11-1.13$ & $1.13-1.11$ & $1.25-1.26$ & $1.15-1.16$ \\
\hline$\left(K_{0}-K_{\text {end }}\right)_{\text {electrolyte }} / \mu \mathrm{S} \mathrm{cm}^{-1}$ & $798-760$ & $730-694$ & $745-709$ & $736-701$ & $759-720$ & $684-670$ \\
\hline samples densities, $\rho / \mathrm{g} \mathrm{cm}^{-3}$ & 5.78 & 3.61 & 5.53 & 4.74 & 4.32 & 7.39 \\
\hline
\end{tabular}




\section{Results and discussion}

\subsection{Microscopic results}

The SEM image of SbS40 (Fig. 4a) shows the dispersion of salt in the metal matrix.

These particles maintained practically the same initial dimensions and cuboid shape with good dispersion thus having considerable influence on all intrinsic properties of the foams prepared by ESR method.

In order to explore the chemical composition of the cell walls, which has great impact on the electrical performance and consequently on the lead-acid battery, backscattered electron composition (BEC) was conducted before and after salt leaching, because any physical or chemical changes are very important. All the changes that may have occurred during the process had been detected and a protocol of reactions was proposed based on BEC images, EDS spectrum, and previous research realized in this field (because of lack of means).

Backscattered electron composition image (BEC) in Fig. 4b shows a thin film of crystals clearly surrounding each grain of $\mathrm{NaCl}$, with thickness of approximately $10 \mu \mathrm{m}$ or less . This crust may be formed during the contact of melting alloy with the salt particles or during foam cooling step. However, it is represented by two distinct types of crystals.

Fig. 5a shows these crystals clearer: the most common first form is elongated prismatic tubular shape (red cross $(+)$ ).
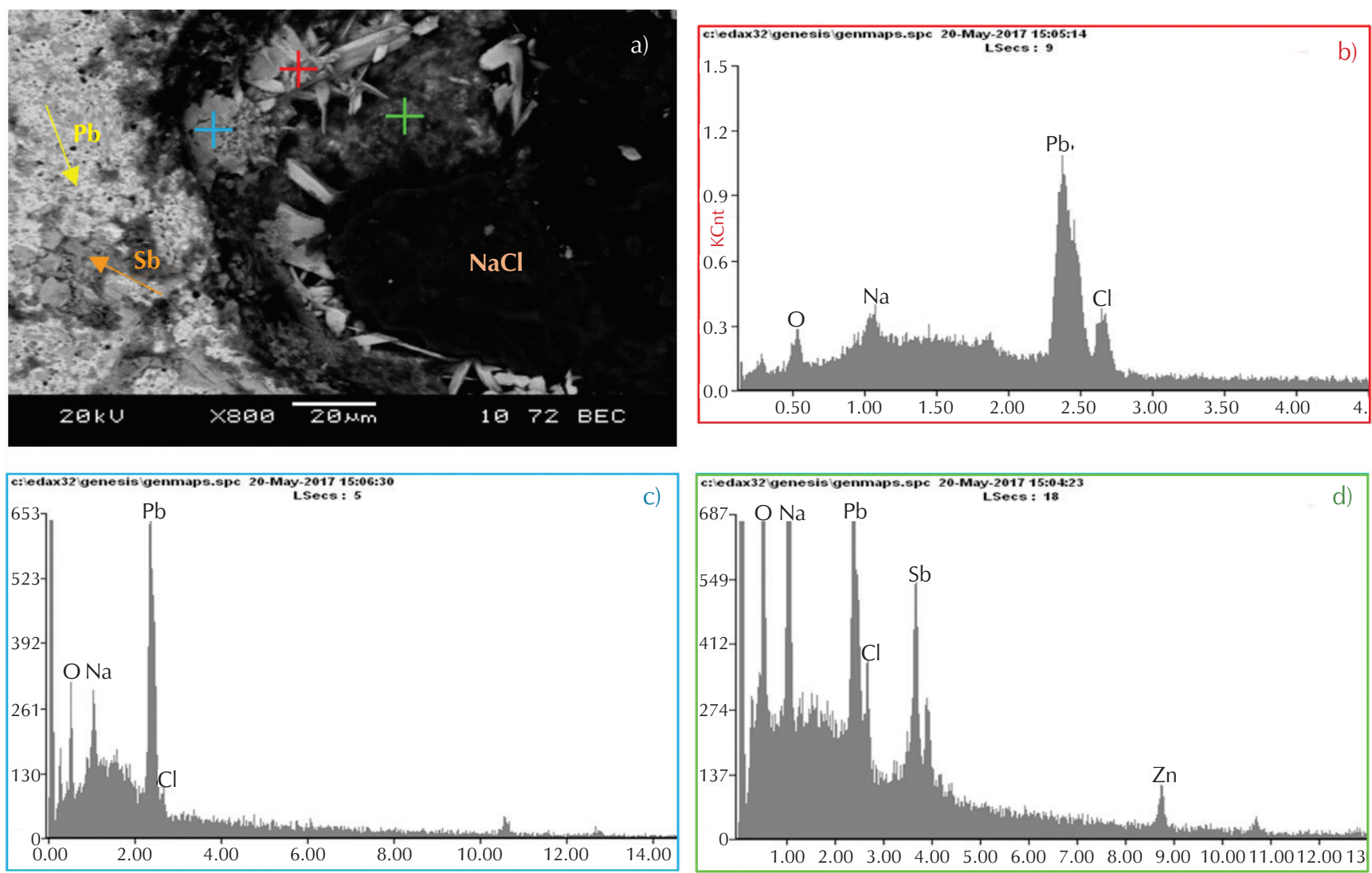

Fig. 5 - (a) SEM image of SbS40 foam with JEOL JSM-6360. EDXS of different lead oxide crystals on (b) and (c) before NaCl leaching. (d) EDXS of the metal matrix in contact with salt grains of SbS40.

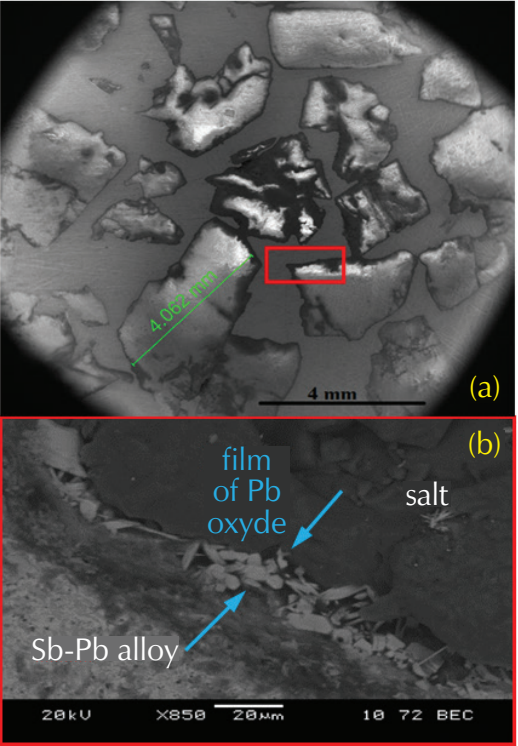

Fig. 4 - (a) Quanta 650 SEM images of salt dispersion in the metal matrix of SbS40. (b) Magnification of the existing film between salt grain and antimonial lead alloy in SbS40 sample obtained with JOEL JSM-6360 before $\mathrm{NaCl}$ leaching.

The blue cross represents the second form, which takes the appearance of snowflakes mass with thin reticulated and delicate crystals. Energy dispersive X-ray spectroscopy 

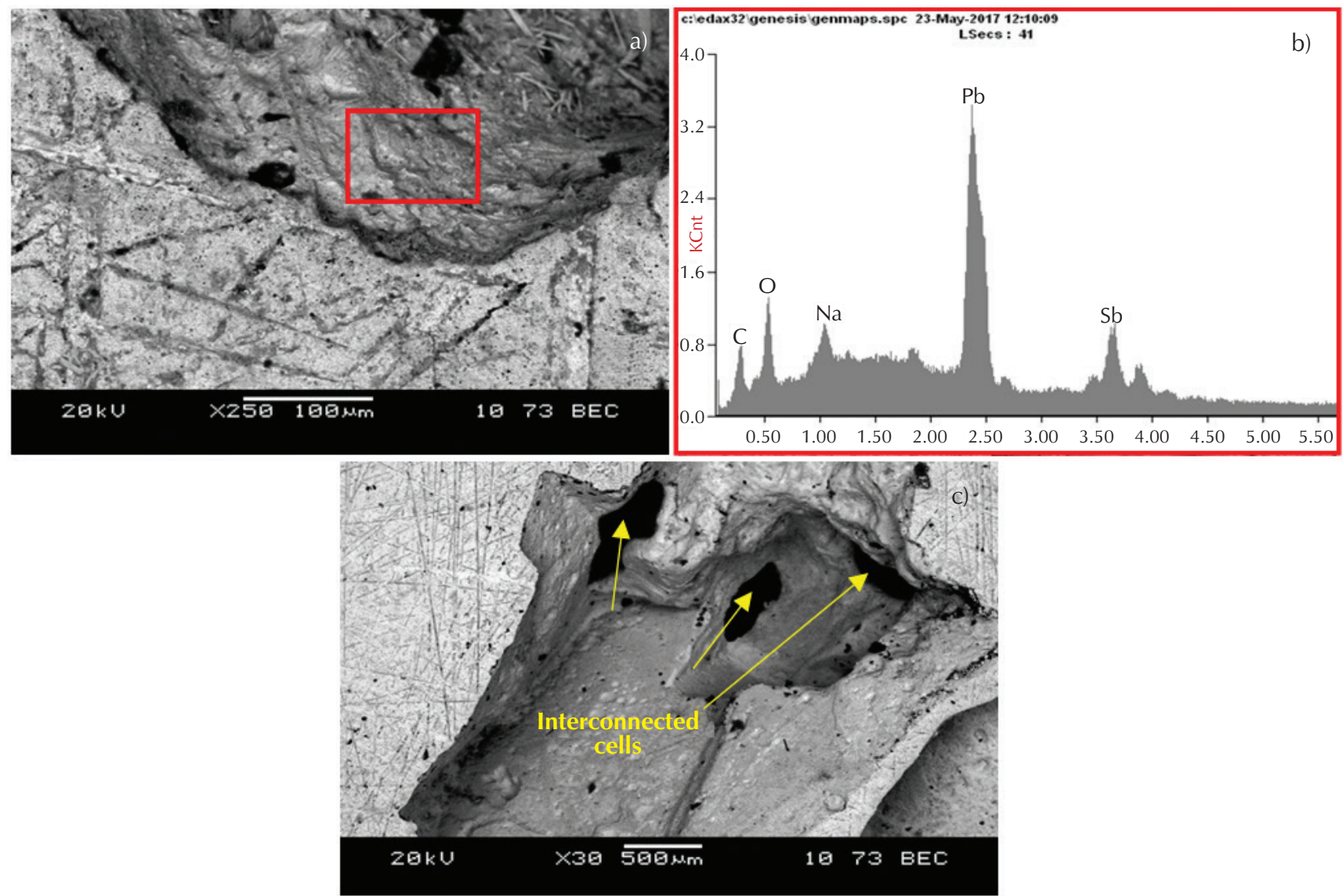

Fig. 6 - JOEL JSM-6360SEM investigations of SbS40 after salt leaching. (a) Image of cell wall. (b) EDS spectrum representing the pore chemical composition. (c) Cell interconnections by the bias of micro pores.

of these crystals before leaching the salt, revealed the presence of $\mathrm{O}, \mathrm{Na}, \mathrm{Pb}$, and $\mathrm{Cl}$ elements only. The two forms had the same mass fraction of $\mathrm{Pb}$, but mass fraction of $\mathrm{Cl}$ was five times higher in laminated crystals in Fig. 5b than the snowflakes mass in Fig. 5c. This latter form had twice the elevated mass fraction of $\mathrm{O}$ than the laminated form. The amount of $\mathrm{Na}$ had not changed significantly. The Sb was present in the wall-like cell depicted clearly in Fig. $5 d$ (green cross in Fig. 5a) with mass fraction of $22.54 \%$, and completely missed in the two forms of crystals. This indicated that $\mathrm{Sb}$ had not reacted along the process, perhaps due to the Sb melting temperature practically close to the operating fusion temperature. The presence of $\mathrm{Zn}$ was due to the impurities from the box containing salt particles. As the process was tried in the atmospheric ambiance, the presence of oxygen at elevated temperature caused the oxidation of lead, giving lead oxides or hydroxides. If hydrogen $(\mathrm{H})$ cannot be identified by EDS detectors, it doesn't mean it doesn't exist in the oxide crystals (it has only a K layer electron, so no characteristic X-ray can be emitted).

The BEC imaging principle states that chemical elements with higher atomic number appear brighter than those having lower atomic number. ${ }^{18,19}$ This suggests that, due to high lead atomic number in comparison with antimony, the few dark grey regions in Fig. 6a represent the Sb phase, and the light grey regions, mostly abundant, represent $\mathrm{Pb}$ phase in the Sb25\%-Pb75\% alloy.
According to researchers ${ }^{20,21}$ and many others, such chemical composition and morphology of crystals are characteristic of lead oxides which are formed in the presence of $\mathrm{O}_{2}$, and then subsequently converted to hydrocarbonates in the presence of carbon dioxide $\left(\mathrm{CO}_{2}\right)$ and water $\left(\mathrm{H}_{2} \mathrm{O}\right)$; like in our case after leaching the salt (Fig. 6a). The EDS spectrum of the cell wall in Fig. 6b confirms this conclusion. The chemical composition of the unit cell was: $\mathrm{C}, \mathrm{O}$, $\mathrm{Pb}, \mathrm{Na}$, and $\mathrm{Sb}$ (perhaps undetectable $\mathrm{H}$ ), with low wt\% of $\mathrm{Na}$, and the absence of $\mathrm{Cl}$ after $\mathrm{NaCl}$ leaching.

It can be concluded that metallic lead was transformed to lead oxides, then to lead carbonates by oxidation before salt leaching, followed by the carbonization after $\mathrm{NaCl}$ leaching. This generated cell wall of thin white crust acting as a protective coat, as reported by many researchers. ${ }^{22,23,24}$

The lead oxides present a complex set of chemical and physical properties, and a wide variety of chemistry approaches ${ }^{25}$, and without differential thermal analysis equipment, the exact oxides and carbonates compound formulations, even at the stage of their development, shall remain difficult to determine. Researchers ${ }^{26,27}$ underlined the importance of lead carbonates for lead-acid battery chemistry. Their presence in the battery plates increases the resistivity of the electrolyte. 


\subsection{Mechanical results}

Strong and shock-resistant battery plates are of great interest, so the study of their mechanical behaviour is important. The mechanical properties of the foams prepared by ESR method were completely dependent on the cells dimensions and the physical properties of the matrix alloy. The SEM image presented in Fig. 6c shows open interconnections between foam cells after $\mathrm{NaCl}$ removal, which appear as black micro-holes.

The compressive engineering stress - engineering strain curves corresponding to all tested specimens and plotted in Fig. 7a, had the same mechanical behaviour as all other open cell replicated foams as those described in refs. ${ }^{14,28,29}$ The graphs clearly depict three distinct regions of deformation. The first one is a linear elastic region, where the stress rises linearly with increasing strain, in turn controlled by the elastic flexion of both the edges and walls of the cells. The end of this linear segment gives the compressive yield strength, which is simultaneously the beginning of the second region, where the cells collapse progressively and the variation of stress is nearly constant: this is "the plastic plateau". The third region, when all cells are crushed, gives rapid increase of the stress, the so-called "densification region". ${ }^{14}$

Note that plateau stress of SbS25 and SbS30 is: smooth, close, and the longest; while their porosities are completely different and their cell sizes are closed. The same remarks can be found for the couple of SbS35/SbS40 and SbS45/SbS50. The SbS25, SbS30, and SbS50 specimens give plateaux stress three times longer than the others, which renders them more likely energy absorbers than the other foams, because of the presence of more cells and the struts resisting collapsing, thus increasing the plasticity at this region. There is no noticeable direct relation between the variations of salt grain size and the plateau stress. The inset in Fig. $7 \mathrm{~b}$ represents an identical elastic behaviour of all the samples, which was expected because in this region, the elastic deformation occurs at interatomic bonds of the same metal, and its atoms return to their original positions when the load is removed. SbS25 linear elastic region is relatively shifted because the sample faces a misalignment and not due to a lack of parallelism of the platens of compression. ${ }^{30}$ The plateau stress of SbS35 and SbS40 is two times greater than that of SbS45 and SbS50, and three times than that of SbS25 and SbS30, which make them the stiffest ones. In order to consider the reproducibility and uniformity all along the specimen, we tested two identical discs machined from the same sample SbS30, presented in Fig. 7c, and plotted their engineering stress-strain curve, as in Fig. $7 \mathrm{~d}$. It seems that there is a noticeable similarity of the results obtained along the same foam, which confirms the stability of the process along every sample.

The linear relation between the plateau stress $\sigma_{\mathrm{p}}$ and the relative density $R_{\mathrm{D}}=\rho / \rho_{0}$ proposed by Ashby et al., introduced earlier for the currently available open cell metal foam,,$^{13}$ gives the parameter $n$ as rule of thumb a value of 1.6. This important constant, characterising in a classical way the scaling laws for the foams mechanical properties (especially for compressive strength vs. relative density), was identified and obtained as $n=1.63$ (Fig. 8a). Nevertheless, the corresponding factor regarded as the product between a material constant $C$ and the solid plastic yield stress $\sigma_{y, s}$ is $C \sigma_{y, s}=19.78 \mathrm{MPa}$, which leads to a constant $C=0.54$ rather than 0.34 because the apparent yield stress $\sigma_{y, s}=\sigma_{0}$ of solid antimony alloy is about $36.83 \mathrm{MPa}$. These results mean that these foams prepared by ESR method give interesting compressive strength properties. Starting from the Ashby Eq. (1), the following experimental estimation of plateau stress ratio variation with the relative foam density was obtained:

$$
\sigma_{\mathrm{p}} / \sigma_{0}=0.54\left(\rho / \rho_{0}\right)^{1.63}
$$

The empirical relation (3) allows the prediction of porosity of the future $25 \%$ antimony-lead alloy foams produced with this ESR process for a specific compressive strength before elaboration. Regarding the relative high density ra-
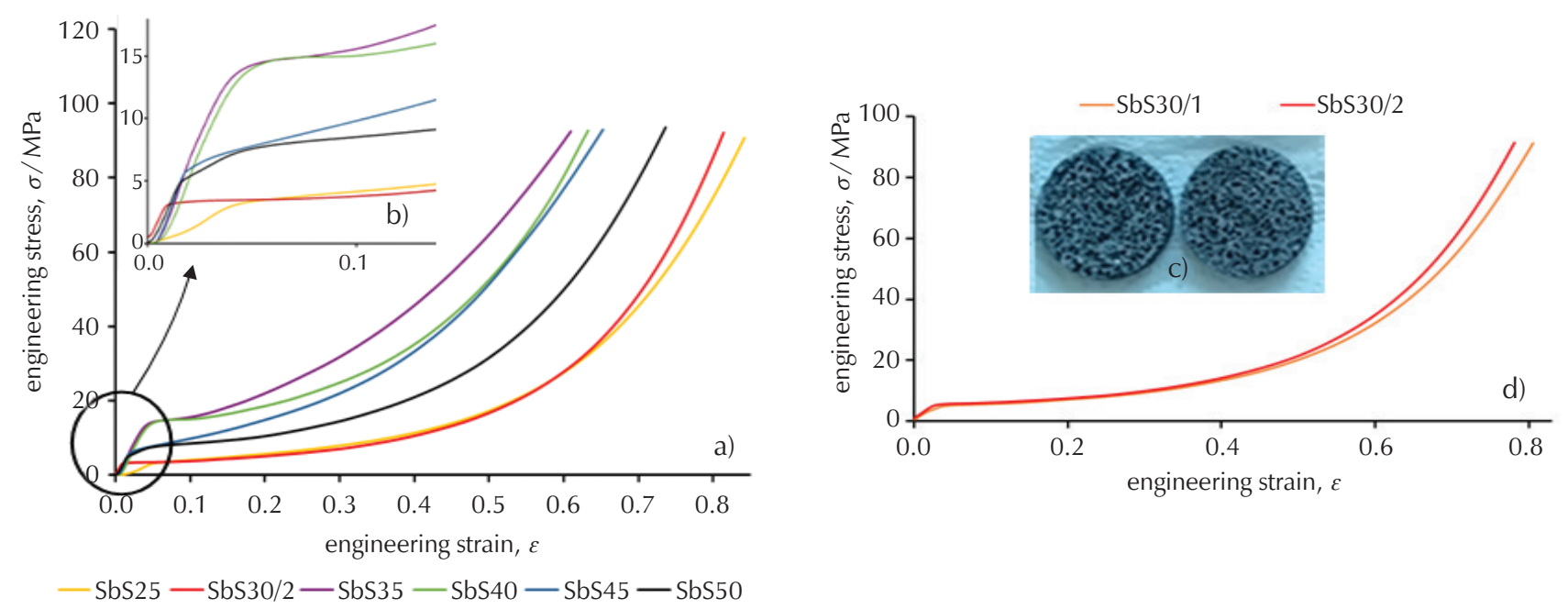

Fig. 7 - (a) Engineering stress-strain behaviour of all six samples of SbS foams. (b) Extension of elastic zones providing a superposition of all graphs regardless of the SbS25. (c) Two different parts of the same foam SbS30 sample showing the reproducibility of the process. (d) Engineering stress-strain curve of two different parts pictured in (c). 
tio, in order to take into account a gradual increase in plateau stress to the value corresponding to complete densification $\left(\sigma_{\mathrm{p}} / \sigma_{0} \approx 1\right.$ if $\rho / \rho_{0} \rightarrow 1$ ), based on a Féret model, and new generalised laws proposed by A. Belhadj \& A Gavrus et al. in ref. ${ }^{14}$, the following approximate expressions of plateau stress ratio variation were obtained:

$$
\begin{gathered}
\sigma_{p} / \sigma_{0} \approx 1 \cdot\left(\rho / \rho_{0}\right)^{2.25}, \\
\sigma_{p} / \sigma_{0} \approx 10.5\left\{1-\exp \left[-0.1\left(\rho / \rho_{0}\right)^{2.25}\right]\right\} \text { or } \\
\sigma_{p} / \sigma_{0} \approx 1.2\left\{1-\exp \left[-0.1\left(\rho / \rho_{0}\right)^{25}\right]\right\}^{2.25 / 25}
\end{gathered}
$$

To compare the current results with the literature data of many studies on such alloy foams using a similar salt replication technique, aluminium foams were selected, for which this elaboration method seemed to be more appropriate.

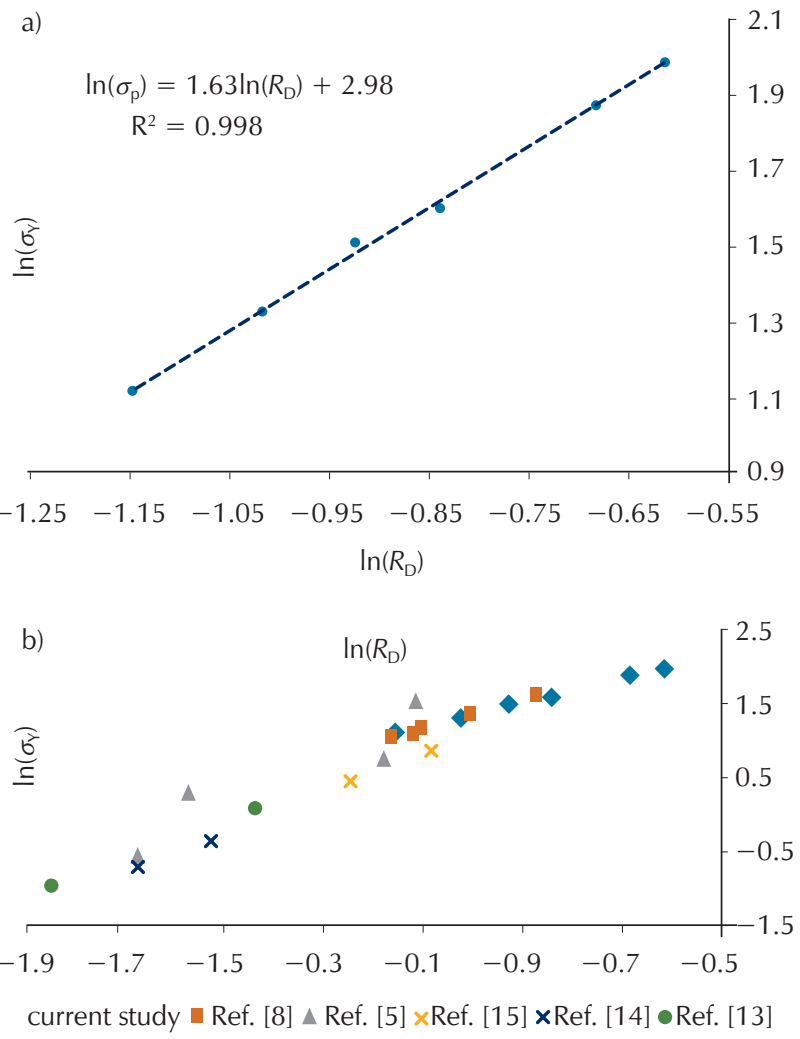

Fig. 8 - (a) Logarithmic plot of plateau stress vs. relative density obtained by ESR process during this study. (b) Logarithmic plot of yield strength vs. relative density $\left(R_{\mathrm{D}}=\rho / \rho_{0}\right)$ for all foams of the current study $(2.5-5 \mathrm{~mm}$ pore size) in comparison to those similarly studied in literature.

Logarithmic plot of compressive yield strength $\sigma_{y}=\sigma_{\mathrm{p}}$ vs. relative densities $R_{\mathrm{D}}$ of all foams obtained by this new process is drawn in Fig. 8a together with those cited in refs. ${ }^{11,31-33}$ plotted in Fig. 8b (obtained with pure alumin- ium for cell diameter of $400 \mu \mathrm{m}$, and porosity range between 66 and $81 \%$, and the result obtained by ${ }^{16}$ (with Sn50 \%-Pb50 \% alloy, pore size 1.6-4 mm, and the porosity range between 58 and $68 \%$ ). It is clear that the yield strength follows the behaviour trend of data taken from the scientific literature, but with better compressive strength properties (when considering the same salt grain size). This result encourages their use in lead-acid batteries for the manufacture of stronger cellular electrodes with the wellknown lead-antimony alloys.

The same porosities gave the same compressive yield strength even when the salt grain size differed, and independently of the alloy or metal used, or the process employed. From the literature, when porosity increased, the compressive yield strength decreased for identical grain size and metal, because the struts and cell walls were less rigid. The ESR process gave foams with decreasing strength for increasing porosities regardless of cells diameter.

\subsection{Electrochemical results}

As mentioned previously, all studies concerning energy storage field try to enhance the performance of batteries and lighten their weight, which was explored in this final section. In order to investigate the electrical performance of these foams prepared by ESR method; if employed as positive electrodes in lead-acid batteries with a standard classical lead dense plate as negative electrode, in comparison to the performance of the same alloy ( $25 \%$ antimony-lead) in dense form; electrical conductivity value was measured using a SELECTA CD-2005 Conductivity Meter.

The plot of the electrical conductivity $к$ of sulphuric acid with immerged foam electrodes in Fig. 9a (regarded as the measurement of an apparent electrolyte-foam interaction conductivity) clearly shows the superiority performance of all foams in comparison with the use of the dense alloy of the same composition (non-porous) as electrodes, regardless of their density. This is due to the remarkable specific surface that these foams present. ${ }^{34}$

Best performance among all cells was that of SbSPb20, which showed higher specific active surface. Therefore, compressive strength and porosity toward the electrical performance must be considered when manufacturing electrodes. The conductivity of an electrolyte depends on the amount of free water $\mathrm{H}_{2} \mathrm{O}$ that it contains, ${ }^{35,17}$ which means the decreased look of conductivity during all tests due to the spontaneous activity of water $\left(\mathrm{H}^{+}\right.$ions consumption).

Boggio et al. ${ }^{36}$ showed that the presence of antimony influenced the lead dioxide crystalline structure by increasing the quantity of charge involved in the reduction to $\mathrm{PbSO}_{4}$ and decreasing the oxygen overvoltage on $\mathrm{PbO}_{2}$, which took place when the electrode was dipped into the electrolyte (zone I in Fig. 9a). The batteries spontaneous discharging continues slowly over zone II in Fig. 9a with well described redox reactions. ${ }^{37}$

Zone III in Fig. 9a describes the equilibrium of electrons flux in the circuit, meaning that the electric conductivity (spontaneous discharging) has reached lower limit. The 

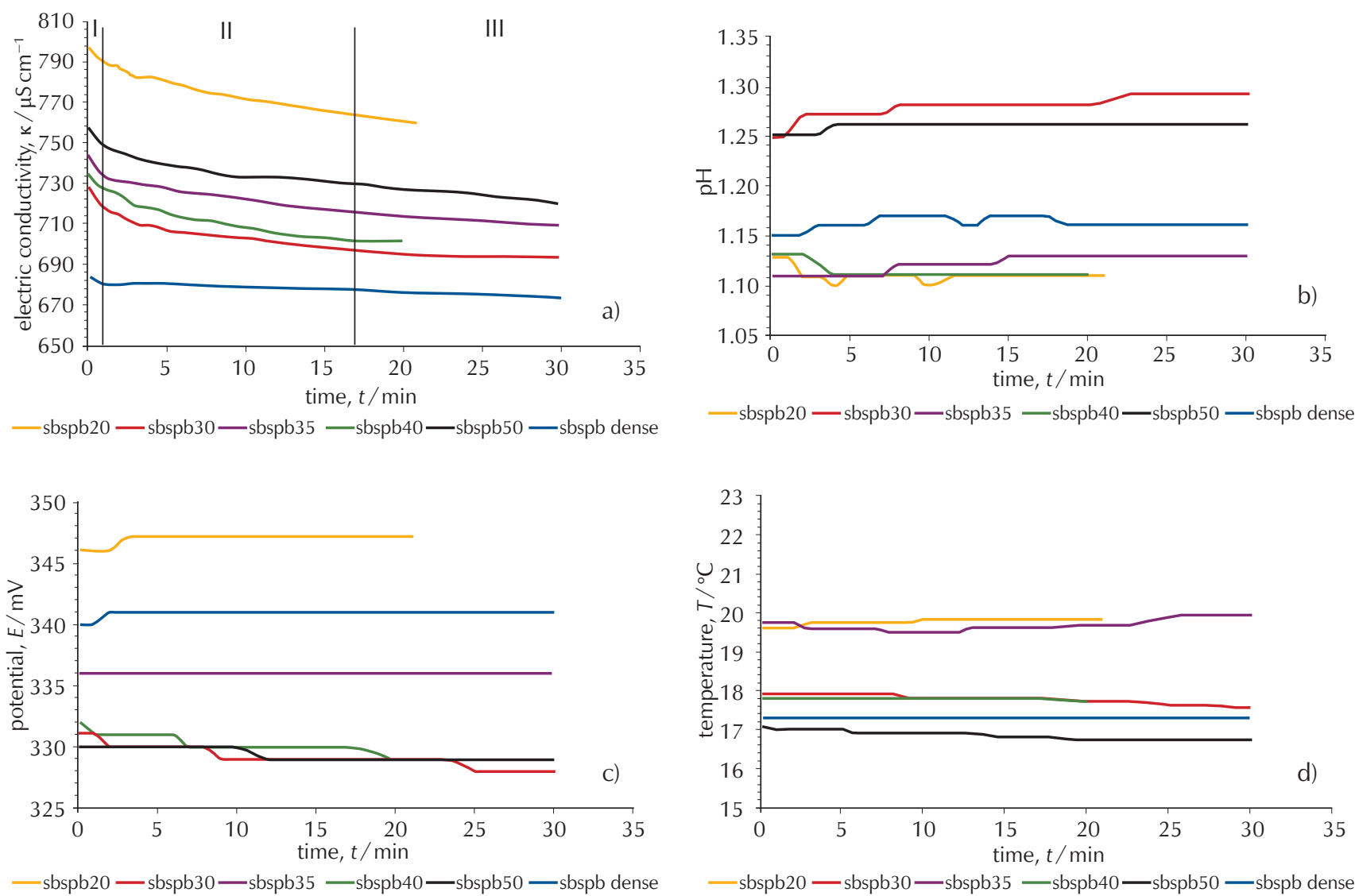

Fig. 9 - (a) Sulphuric acid electric conductivity graphs of all cells in comparison with standard SbPb dense electrode. (b) Electrolyte $\mathrm{pH}$ plots for all foams prepared by ESR method. (c) Potential difference measured during battery spontaneous discharging. (d) Representation of electrolyte temperature during tests for all foams prepared by ESR method with respect to the dense material of the same composition showing the thermal stability of the system.

representation of $\mathrm{pH}$ in Fig. 9b confirms the conductivity behaviour: a stable $\mathrm{pH}$ corresponds to zone I of the conductivity. This correspondence means that there is a compensation of $\mathrm{H}^{+}$consumption at lead anode $(\mathrm{Pb}$ oxidation gives 2 electrons to water which electrolyses); by lead dioxide reduction at cathode (giving $2 \mathrm{H}_{2} \mathrm{O}$ ). Then, $\mathrm{pH}$ increases slightly meaning that the solution has become alkaline. This is the stage of deposition of lead sulphate $\mathrm{PbSO}_{4}$ formed at cathode, inside the porous foams, on the lead dioxide cell wall, reducing the active surface.

Fig. 9c depicts the corresponding potential difference $E$, which is tightly dependant on the $\mathrm{pH}$ of electrolyte. It is obvious that when $\mathrm{pH}$ decreases, the corresponding voltage increases, for all foams prepared by ESR method (but SbSPb40 presents aberrant values), because of the chemical species undergoing reduction and oxidation in the electrolyte (Nernst equation).

Thermal stability of the batteries was simultaneously investigated leading to a good result. Fig. 9d shows a relatively constant temperature of the electrolyte for all batteries during the tests. Therefore, thermal stability of the battery is proven, implying safety of usage.

Because of the rareness of research on electrical conductivity in replicated open cell foams, the generalised equa- tion of Ashby for relative dense cellular metals can be used to link the effective electrical conductivity of our foams to their relative density written in the form:

$$
K^{\prime} / K_{0}^{\prime}=\alpha\left(\rho / \rho_{0}\right)+(1-\alpha)\left(\rho / \rho_{0}\right)^{3 / 2}
$$

where $K$ and $\rho$ are the effective property and density of the foam, respectively, while $K_{0}$ and $\rho_{0}$ are the corresponding properties of the employed dense alloy.

The first term of Eq. (5) describes the contribution of struts, and the second term that of nodes, while the introduced structural parameter $\alpha$ describes the distribution of the material between cell nodes and struts. In the first approximation regarding that the electrolyte has a higher conductivity compared to the electrodes, the measured apparent electrolyte-foam electric conductivity ratio $K / K_{0}$ can be supposed rather proportional to the ratio of the effective foam conductivity $K^{\prime} / K_{0}^{\prime}$, and can be estimated from the experimental data in Fig. 9, rather on the magnitude values point of view. All the parameters of Ashby relationships (5) are identified by non-linear regression, and the following approximate equation is obtained: 


$$
K^{\prime} / K_{0}^{\prime} \approx 7.65\left(\rho / \rho_{0}\right)-6.65\left(\rho / \rho_{0}\right)^{3 / 2}
$$

Therefore, in case of the foams prepared by ESR method, the dimensionless structural parameter $\alpha$ has a very high magnitude value ( $\alpha=7.65)$, caused especially by the anisotropic orientation of the cells, their real irregular shape, the approximation of the experimental measurement method based on the apparent electrolyte-foam interaction conductivity, and the use of a different alloy types. A negative contribution of the cell nodes compared to the core material is observed due to the high electrical conductivity of the antimonial lead foams, which is supposed to be otherwise, rather than inverse case. Thus, no comparison is possible because the parameter $\alpha$ must be estimated experimentally for each material, it is valid only for a certain density range $\mathrm{e}^{38}$ and needs precise and direct measurements of foam conductivity.

\section{Conclusion}

Good open cell foams are made with this promising excess salt replication process. Different porosities were obtained by employing $25 \%$ antimonial-lead alloy as a metal matrix. The SEM investigations of cells revealed the presence of lead oxides crystals formed between the preform grains and the solid metal matrix, then transformed to lead carbonates after salt leaching, which were of great interest for lead-acid batteries. The cell shapes were replicas of the used $\mathrm{NaCl}$ grains (after dissolution of the salt, the cells preserved the original forms of the grains of salt). The plateau stress of all samples presented smooth curves with a pronounced plateau stress, which confirmed the advanced expectations. The unconventional important density of the foams prepared by ESR method was typical of this kind of alloy giving higher compressive yield strength, and leading them to be proposed as good shock absorbers. An empirical relation was proposed to predict the compressive strength of such foams in terms of desired porosity. The good electrical properties of these foams in comparison to the dense alloy of the same composition and their thermal stability make them most suitable as cathode in lead-acid batteries. Further characterisations have been undertaken to understand and classify the products of this process.

\section{References \\ Literatura}

1. C. Italiano, P. Lidia, M. Lagana, V. Antonio, Ceramic monolith-and foam-structured catalysts via in-situ combustion deposition for energetic applications, Lavoisier, 2018, 405, doi: https://doi.org/10.3166/acsm.42.405-418.

2. R. Goodall, A. Mortensen, 24 - Porous Metals, in: Physical Metallurgy, Elsevier, 2014, p. 2399-2595, doi: https://doi. org/10.1016/B978-0-444-53770-6.00024-1.

3. J. Despois, A. Marmottant, L. Salvo, A. Mortensen, Influence of the infiltration pressure on the structure and properties of replicated aluminium foams, Mater. Sci. Eng A. 462 (2007) 68, doi: https://doi.org/10.1016/j.msea.2006.03.157.

4. J. Banhart, Manufacture, characterisation and application of cellular metals and metal foams, Prog. Mater. Sci. 46 (6) (2001) 559-632, doi: https://doi.org/10.1016/S00796425(00)00002-5

5. Z. Ghasemi, A. Tizpar, Studies on Corrosion Resistance and Electrochemical Behavior of Pb-Sb-As-S Alloys as Positive Grids in Lead-acid Batteries, Int. J. Electrochem. Sci. 2 (2007) 700-720.

6. F. M. Reinhart, J. F. Jenkins, Corrosion of materials in surface seawater after 12 and 18 months of exposure, Naval Civil Engineering Lab Port Hueneme CA, 1972, doi: https://doi. org/10.5962/bhl.title.47714.

7. R. J. Hill, Structure of $\mathrm{PbSb} 2 \mathrm{O} 6$ and its relationship to the crystal chemistry of $\mathrm{PbO}_{2}$ in antimonial lead-acid batteries, J. Solid State Chem. 71 (1987) 12-18, doi: https://doi. org/10.1016/0022-4596(87)90136-8.

8. R. Goodall, A. Mortensen, 24 - Porous Metals, in: Physical Metallurgy, Elsevier, 2014, p. 2399-2595, doi: https://doi. org/10.1016/B978-0-444-53770-6.00024-1.

9. B. Soni, S. Biswas, Development of Al Foams by a Lowcost Salt Replication Method for Industrial Applications, Mater. Today Proc. 2 (2015) 1886-1891, doi: https://doi. org/10.1016/j.matpr.2015.07.140.

10. S. Aida, M. Hijrah, A. Amirah, H. Zuhailawati, A. Anasyida, Effect of $\mathrm{NaCl}$ as a space holder in producing open cell A356 aluminium foam by gravity die casting process, Procedia Chem. 19 (2016) 234-240, doi: https://doi.org/10.1016/j. proche.2016.03.099.

11. R. Jamshidi-Alashti, G. Roudini, Producing replicated opencell aluminum foams by a novel method of melt squeezing procedure, Mater. Lett. 76 (2012) 233-236, doi: https://doi. org/10.1016/j.matlet.2012.02.088.

12. A. Jinnapat, A. Kennedy, The Manufacture and Characterisation of Aluminium Foams Made by Investment Casting Using Dissolvable Spherical Sodium Chloride Bead Preforms, Metals 1 (2011) 49-64, doi: https://doi.org/10.3390/ met1010049.

13. M. F. Ashby, T. Evans, N. Fleck, J. W. Hutchinson, H. N. G. Wadley, L. J. Gibson, Metal Foams: A Design Guide, Elsevier Science, 2000.

14. A.-E. Belhadj, A. Gavrus, F. Bernard, M. Azzaz, Mechanical and Numerical Analysis Concerning Compressive Properties of Tin-Lead Open-Cell Foams, J. Mater. Eng. Perform. 24 (10) (2015) 4140-4155, doi: https://doi.org/10.1007/ s11665-015-1673-0.

15. P. Ruetschi, Review on the lead-acid battery science and technology, J. Power Source. 2 (1977) 3-120, doi: https:// doi.org/10.1016/0378-7753(77)85003-9.

16. A.-E. Belhadj, S.-A. Kaoua, M. Azzaz, J. D. Bartout, Y. Bienvenu, Elaboration and characterization of metallic foams based on tin-lead, Mater. Sci. Eng. A. 494 (2008) 425-428, doi: https://doi.org/10.1016/j.msea.2008.04.040.

17. R. Biagetti, Fabrication of lead-acid batteries, Google Patents, 1973.

18. G. E. Lloyd, Atomic number and crystallographic contrast images with the SEM: a review of backscattered electron techniques, Mineral. Mag. 51 (1987) 3-19, doi: https://doi. org/10.1180/minmag.1987.051.359.02.

19. J. I. Goldstein, D. E. Newbury, P. Echlin, D. C. Joy, C. E. Lyman, E. Lifshin, L. Sawyer, J. R. Michael, The SEM and Its Modes of Operation, in: Scanning Electron Microscopy and X-Ray microanalysis, Springer, 2003, p. 21-60, doi: https://doi. org/10.1007/978-1-4615-0215-9_2.

20. Y. Li, Y. Zhu, S. Zhao, X. Liu, The weathering and transformation process of lead in China's shooting ranges, Environ. Sci. Process. Impact. 17 (2015) 1620-1633, doi: https://doi. 
org/10.1039/c5em00022j.

21. L. Q. Ma, D. W. Hardison, W. G. Harris, X. Cao, Q. Zhou, Effects of soil property and soil amendment on weathering of abraded metallic $\mathrm{Pb}$ in shooting ranges, Water Air Soil Poll. 178 (2007) 297-307, doi: https://doi.org/10.1007/s11270006-9198-7.

22. T. Graedel, Chemical mechanisms for the atmospheric corrosion of lead, J. Electrochem. Soc. 141 (1994) 922-927, doi: https://doi.org/10.1149/1.2054858.

23. X. Cao, L. Q. Ma, M. Chen, D. W. Hardison, W. G. Harris, Lead transformation and distribution in the soils of shooting ranges in Florida, USA, Sci. Total Environ. 307 (2003) 179189, doi: https://doi.org/10.1016/S0048-9697(02)00543-0.

24. S. S. Jørgensen, M. W. Ambio, The Fate of Lead in Soils: The Transformation of Lead Pellets in Shooting-Range Soils, JSTOR 16 (1987) 11-15, url: https://www.jstor.org/stable/4313312.

25. A. Facchetti, T. Marks, Transparent electronics: from synthesis to applications, John Wiley \& Sons, 2010, doi: https://doi. org/10.1002/9780470710609.

26. S. Krivovichev, P. Burns, Crystal chemistry of basic lead carbonates. I. Crystal structure of synthetic shannonite, $\mathrm{Pb}_{2} \mathrm{O}(-$ $\mathrm{CO}_{3}$ ), Mineral. Mag. 64 (6) (2000) 1063-1068, doi: https:// doi.org/10.1180/002646100550065.

27. I. M. Steele, J. J. Pluthl, A. Livingstone, Crystal structure of macphersonite $\left(\mathrm{Pb}_{4} \mathrm{SO}_{4}\left(\mathrm{CO}_{3}\right)_{2}(\mathrm{OH})_{2}\right)$ : Comparison with leadhillite, Mineral. Mag. 62 (1998) 451-459, doi: https://doi. org/10.1180/002646198547828.

28. B. Jiang, N. Zhao, C. Shi, J. Li, Processing of open cell aluminum foams with tailored porous morphology, Scr. Mat. 53 (2005) 781-785, doi: https://doi.org/10.1016/j.scriptamat.2005.04.055.

29. Y. Zhao, D. Sun, A novel sintering-dissolution process for manufacturing Al foams, Scr. Mat. 44 (2001) 105-110, doi:
https://doi.org/10.1016/S1359-6462(00)00548-0.

30. C. Gaillard, J. F. Despois, A. Mortensen, Processing of $\mathrm{NaCl}$ powders of controlled size and shape for the microstructural tailoring of aluminium foams, Mater. Sci. Eng. A 374 (2004) 250-262, doi: https://doi.org/10.1016/j.msea.2004.03.015.

31. J. Despois, A. Marmottant, L. Salvo, A. Mortensen, Influence of the infiltration pressure on the structure and properties of replicated aluminium foams, Mater. Sci. Eng. A 462 (2007) 68-75, doi: https://doi.org/10.1016/j.msea.2006.03.157.

32. R. Goodall, J.-F. Despois, A. Marmottant, L. Salvo, A. Mortensen, The effect of preform processing on replicated aluminium foam structure and mechanical properties, Scr. Mat. 54 (2006) 2069-2073, doi: https://doi.org/10.1016/j. scriptamat.2006.03.003.

33. R. Goodall, A. Marmottant, L. Salvo, A. Mortensen, Spherical pore replicated microcellular aluminium: Processing and influence on properties, Mater. Sci. Eng. A 465 (2007) 124-135, doi: https://doi.org/10.1016/j.msea.2007.02.002.

34. J. Newman, W. Tiedemann, Porous-electrode theory with battery applications, AIChE Journal. 21 (1975) 25-41, doi: https://doi.org/10.1002/aic.690210103.

35. H. Majima, E. Peters, Y. Awakura, S. K. Park, Electrical conductivity of acidic sulfate solution, Metall. Trans. B 18 (1987) 41-47, doi: https://doi.org/10.1007/BF02658430.

36. A. Boggio, M. Maja, N. Penazzi, Effects of antimony on the electrochemical behaviour of lead dioxide in sulphuric acid, J. Power Source. 9 (1983) 221-230, doi: https://doi. org/10.1016/0378-7753(83)80034-2.

37 P. Delahay, M. Pourbaix, P. Van Rysselberghe, Potential-pH Diagram of Lead and its Applications to the Study of Lead Corrosion and to the Lead Storage Battery, J. Electrochem. Soc. 98 (1951) 57-64, doi: https://doi.org/10.1149/1.2778106

38. H.-P. Degischer, B. Kriszt, Handbook of cellular metals: production, processing, applications, Wiley-vch Weinheim, 2002, doi: https://doi.org/10.1002/3527600558. 


\section{SAŽETAK}

\section{Razrada i mehaničko-elektrokemijska karakterizacija antimon-olovnih pjena s otvorenim ćelijama izrađenim “Metodom prekomjerne replikacije soli” za moguću primjenu u proizvodnji olovno-kiselih baterija Amel Hind Hassein-Bey, ${ }^{a}$ Abd-Elmouneïm Belhadj, ${ }^{a,}{ }^{*}$ Adinel Gavrus, ${ }^{b}$ and Salam Abudurac}

U ovom istraživanju izrađene su otvorene ćelije od $25 \%$ antimon-olovnih pjena za moguću primjenu u osvjetljavanju debelih ploča olovno-kiselih baterija. Razvijena je i istražena nova jeftina $\mathrm{i}$ jednostavna varijanta procesa repliciranja soli. Različite morfologije i oblici uspješno su dobiveni metodom "prekomjerne replikacije soli" (ESR metodom). Najbolja poroznost od oko 68 \% dobivena je pri veličini čestica soli od oko $3 \mathrm{~mm}$. SEM i EDXS ispitivanje kompozitne legure soli/antimona prije ispiranja s $\mathrm{NaCl}$ otkrilo je prisutnost mikrofilma olovnih oksida koji oblažu zidove ćelije i nakon uklanjanja soli postaju olovni karbonati. Jednoosno tlačno ponašanje dobivenih materijala ćelije proučava se za pjene s poroznošću između $45 \%$ i 70 \% i za veličine zrna soli između 2,5 i $5 \mathrm{~mm}$. Postignuta je veća granica stlačivanja u usporedbi s rezultatima o aluminijskim pjenama dobivenim u literaturi. Ponovljivost postupka dokazana je na uzorcima.

\section{Ključne riječi}

Pjena s otvorenim ćelijama, proces replikacije, poroznost, olovno-kisele baterije, stlačivanje-naprezanje, SEM, kisela baterija, vodljivost

a Laboratory of Biomaterials and Transport Phenomena (LBMTP), University Yahia Fares, Médéa, 26 000, Alžir

${ }^{\mathrm{b}}$ Laboratory of Civil and Mechanical Engineering (LGCGM - EA3913), National Institut of Applied Sciences of Rennes - INSA Rennes, Francuska

${ }^{c}$ Department of Mechanical Engineering, Faculty of Technology, University Yahia Fares, Médéa, 26 000, Alžir
Izvorni znanstveni rad Prispjelo 4. siječnja 2020. Prihvaćeno 18. lipnja 2020. 